Илијана Р. Чутура

Универзитет у Крагујевцу

Факултет педагошких наука у Јагодини

Катедра за филолошке науке

https://doi.org/10.18485/ai_petrovic_goran.2020.ch11

821.163.41.09 Петровић Г.

811.163.41'373

\title{
СИНТАКСА И СТИЛИСТИКА НАСЛОВА У РОМАНУ ОПСАДА ЦРКВЕ СВ. СПАСА
}

У раду се анализирају синтаксичке карактеристике и стилске особености наслова у роману Ойсаgа иркве Све$\bar{u} о \bar{\imath}$ Сйаса Горана Петровића. Роман обилује насловима, што је условљено фрагментарношћу текста. Наслови првог и другог нивоа синтаксички и лексички су унифицирани, али наслови трећег (најнижег) нивоа показују изузетан степен разноврсности. Њихова стилска особеност анализира се и с обзиром на начин на који наслов кореспондира са текстом на који се односи.

Кључне речи: наслови, Горан Петровић, роман Оūcaga иркве Светиог̄ Сйаса, синтаксичка организација наслова, стилистика наслова.

\section{1. УВОДНЕ НАПОМЕНЕ}

Предмет рада јесу наслови и поднаслови у роману

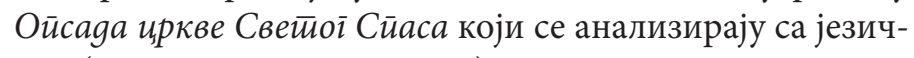
ког (пре свега синтаксичког) и стилског аспекта. Наслови и поднаслови, као својеврстан „позив на читање”

* ilijana.cutura@gmail.com 
и тематска најава онога што следи не могу се заобићи у анализи дела посебно уколико се, као у Oйcagu иркве

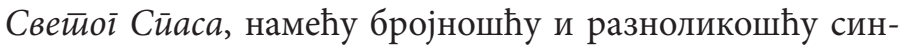
таксичких модела организације.

Бројност наслова и поднаслова у роману предодређена је фрагментарношћу која је „формални облик деконструкције у тексту [и] једна од структуралних и поетичких особености Горана Петровића" (Алексић 2013: 169). Притом, наслови најнижег нивоа у роману

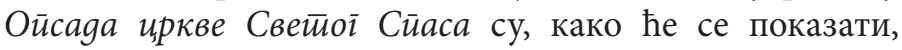
микротекстови посебне категорије који кореспондирају са лексичким и синтагматским елементима текста. У насловима се, као и у другим мањим сегментима, препознаје „аутопоетички захват” - у њима „можемо проникнути у аутореференцијалну свест целог остварења" (Алексић 2013: 106). И као што аутопоетички текст према Брехту има функцију да промовише предмет приповедања из наративно функционалног у тематски значајан елемент (Перишић 2006), ту улогу, на веома сличан начин, имају и наслови сва три нивоа у овом роману: „ако је аутору текста стало да нешто 'каже' и да то нагласи, сигурнији је да ће значење бити примљено ако унапред огласи своју намеру" (Перишић 2006: 406).

Имајући у виду различиту лексичку и синтаксичку структуру наслова и њихову симболичку раван, у првом делу рада ћемо се осврнути на наслове утврђене, једнообразне структуре (наслови првог и другог нивоа), а у другом ћемо анализирати наслове трећег нивоа који су у погледу синтаксичког образовања и лексичког ткива - за разлику од наслова првог и другог нивоа - веома разноврсни. 


\section{2. НАСЛОВИ ПРВОГ И ДРУГОГ НИВОА - КЊИГЕ И ДАНИ}

Роман је организован у девет целина (кюиіа), а оне у укупно четрдесет одељака ( симболиком бројева. Свака књига, од прве до осме, садржи по пет одељака ( (ана), осим девете која садржи само једну целину чији је назив компонован као антитетичка фигура (Конаи или йочело), а почетак истиче симболику броја 40: „Украј чесме, четрдесетак корака наспрам улаза у манастир, био је само неки Блашко...” (369). Већ самим бројем (заокруженошћу као знаком вечности) организација наслова поглавља и одељака упућује на, како је сам аутор истакао у једном интервјуу, главну метафору трагања за мером између прошлости, садашњости и будућности (Интервју, Горан Петровић).

Девет књиїа носе идентично организоване наслове - сваки је именичка синтагма са лексемом кюиіа као главном речју и редним бројем у функцији конгруентног атрибута. ${ }^{1}$ Свака къиїа има и додатни наслов, а сви су именовања за анђеоске чинове (хорове), редом од највишег: серафими, херувими, престоли, господства, силе, власти, начала, арханђели, анђели. Ови наслови, њихова симболика и поетска функција већ су били предмет анализа (в. Алексић 2013: 168-169, Турањанин 2014: 65-66).

1 На скупу смо скренули пажњу на то да су наслови књиїа од првог до четвртог поглавља доследно обликовани по моделу „главна реч + атрибут” (Књига прва, Књига друга...), али да се од петог поглавља прелази на савремени и стилски неутрални ред речи (Пета књига...). Горан Петровић (који је присуствовао скупу) истакао је, међутим, да је и сам изненађен јер није мењао ред речи и да је вероватно у питању техничка омашка издавача (у припреми излагања користили смо издање Народна књига - Алфа из 2004. године). Накнадном провером показало се да су издавачке куће једне од других преузимале модел, те да су у већини издања наслови првог нивоа измењени по аутоматизму. 
Приповедање започиње целинама које су именоване по бићима прве небеске сфере (Небески саветници). То су серафими, чувари Божјег престола, херувими, чувари светлости и звезда, и престоли, господари мудрости, симболи Божије правде и ауторитета (Шаренац 2016: 244). Наредне три кюиіе именоване су по бићима која припадају другој небеској сфери (Небески управитељи): господствима - господарима индивидуалности који „регулишу дужности нижих анђела” (Исто: 245), силама - бићима „која одржавају свемир у равнотежи” (Исто: 245) и властима - носиоцима савести и чуварима историје, господарима ума (Исто: 245).

Приповедање се даље организује по књигама насловљеним према бићима треће небеске сфере (Небески гласници): начала, арханђели и анђели, посредници између Бога и људи, људски заштитници и преноситељи Божјих заповести. Шаренац (2016: 245) закључује: „Оваквом схемом организације структуре романа указује се и на улогу приче, тј. спуштање приче са пиједестала духовног симбола до гашења, запретања и поновног обнављања, до поруке о неуништивости приче, способности обнављања приче, која има вечно трајање.” Небеска бића појављују се на приповедној сцени и редом је напуштају, чиме се непосредност Божје заштите постепено умањује:

Серафими одоше међу звезде (73); Док су унесрећеног износили из цркве, док се народ враћао молитви, игуману Григорију се причини да пера на крилима херувима, горе, шуште некако узнемирено (79); Живу је до темеља одерите! Звона из куле почупајте! Ослепите је да се не гледа са арханђелима! - церекао се напољу слуга Смилец (357); Из неба, болно, запишташе власти. Све што је остало - спусти се, за још десетину хвати висине, у све уже, ноћне вирове (331). 
Прво вићење анђела од стране људског бића везано је за господства с обзиром на то да су небеска бића прве сфере, освећена непосредним озарењима, недоступна виђењу јер су пламтећа услед примања вишње светлости:

Многи су животима јамчили да су и у сну чули многокрило шуштање, баш као да се господства, дошаптавајући, дуго намештају по легалу. Опет, један се слепи клео да их је видео:

- Спрва помислих да сам прогледао! А онда схватих да не разазнајем остало, ни сопствену руку, што сам је испред себе подигао, ни сламу на којој сам лежао, ни оквир прозора кроз који сам зурио, ни Волујаре, ни Месец звезду, него само круне, жезла, оклопе и венац од пламтећих пера! (246).

Поднаслов сваке књиіе јавља се у тексту. Осим већ наведених, појављују се и лексеме ирресииоли, силе, начала, док се анђели појављују у последњој књизи као лебдеће, сачувано перо ангела на самом крају романа:

Види овај! Служи да у небесима разабереш онај свод којим лете богоносни престоли, анђели слични точковима са пламеним паоцима! (181); Из набора небеса, радознало, извиривале су силе. (290); Али, други додају, из небеса се појавише начала, преотеше дечицу, вратише их страторима! - извештавале су оне једна другу, упињући се да разговором заварају материнску бригу. (336)

И наслови других нивоа на сличан начин кореспондирају са лексемама и конструкцијама у тексту.

Не само да се прича „осипа” у смислу спуштања са нивоа присуства и заштите бића најближих Богу, ${ }^{2}$ већ

2 Хијерархија небеских бића је, осим за близину и степен посредности Божје заштите, везана и за лепоту у уметности: „Лепота у уметности, сматрају свети Оци Византије, треба 
се њен опсег и моћ умањују и математички прецизно компонованим поглављима. Иако, наиме, свака кюиїа (1-8) садржи исти број потпоглавља (gана), број најмањих целина (одељака, епизода) у њима смањује се за по четири. Од укупно 89 таквих целина, 25 је у првој, а једна у деветој къизи. ${ }^{3}$ На тај начин Петровић и композицијом и формом, „нема сумње, хтео да подупре основну смисаону нит романа (а њу је могуће видети у истицању значаја приче и у некој врсти предности приче над историјом, пошто прича може да говори и о ономе што историчаре не занима и што ниједна историја не садржи), показујући како прича постепено цури, како се она, идући од почетка према крају, и сама претвара у левак” (Микић 2005: 289). На крају Кюиіе осме, четрдесетог дана, остаје само да се забележи: „Од свега није више ништа остало, ни да се приповеда” (365). У том смислу, али и у смислу односа историје и приче, својеврсни кључ романа представљају епизоде Сусрети йриче и истиорије (Микић

да буде као и сама творевина симболичка и да сведочи о хијерархијском устројењу света. По мишљењу Теодора Студита такође је неопходно тежити созерцању анђелских небеских сила, тамошње неизречене и неизјашњене лепоте, блиставога боравишта апостола, пророка, мученика и свих праведних; сам небески свод, Сунчева светлост, Месечев сјај, хорови анђела и сви други чулима приметни предмети - нису ту да би се на њима зауставили, него да бисмо уз њихово посредовање, созерцавајући Творца свега постојећега, сачували своју красоту неповређеном" (Ристић Горгиев 2003: 194-195). Ова би се чињеница такође могла довести у везу са скраћивањем приче, односно опадањем обима уметничког приповедања (осим дужине, тридесет седми и тридесет девети gан доносе транспоноване неуметничке текстове).

3 Категорија броја као знака самерљивости веома је важна за средњовековног човека (Ле Гоф 2007: 37), те се може претпоставити да Петровићева „математичка” прецизност и на овај начин упућује на средњовековни систем мишљења и доживљавања света. 
2005: 292) и исповести неименованог приповедача:

Отета област може да се поврати, отрок да се искупи из заробљеништва, златар може да скује нову почелицу, ткач да изатка нову одежду, али је за добру причу потребито да неколико поколења на добро дела. Нека Грци понесу, како је и домаћински, колико им стане у ушеса. Али, преко тога - ни слова. Затребаће нама. Нису све године родне, буде столеће и више да нема шта да се приповеда, а тада раба у животу држи да се прегризе макар једна те иста прича. (276)

Као и наслови книі $а$, и четрдесет наслова потпо-

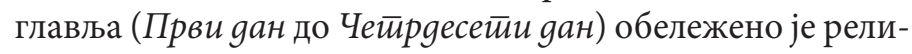
гијском симболиком (в. Алексић 169). Ови су наслови такође синтаксички једнообразни и лексички предодређени.

\section{3. НАСЛОВИ ТРЕКЕГ НИВОА}

Четрдесет потпоглавља, насловљена са „Први дан” до „Четрдесети дан” раздељена су у одељке. Како смо већ напоменули, наслови одељака (трећег нивоа) лексички и синтаксички потпуно одударају од наслова првог и другог нивоа с обзиром на то да нису унифицирани као наслови виших целина. У одељцима су текстови различити по дужини - од неколико страна па до једног пасуса, а први поднаслов Осмоі gана у Кюизи gруіој (Херувими) - „Ноћ” - односи се на пар празних страница. ${ }^{4}$ Наслов изостаје у првом потпоглављу Девейоі̄ gaна, које почиње и завршава се реченицама: „Моје име је мало. И да га чујеш, не би га упамтио" $(270,272)$ и можда је кључ изостанка наслова у „безимености” наратора, Данила Дру-

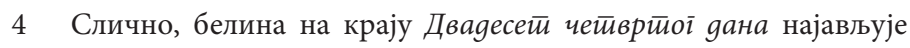
неми говор (287-288). 
гог. Међутим, „Петровић је маестрално средњовековног хагиографа преобратио у свезнајућег творца литерарног света" (Канић 2013: 141). Иако је његов идентитет заогрнут топосом афектиране скромности (Трифуновић 1990: 199-221), он је „свезнајући творац литерарног света” који у роману исприповеданом у трећем лицу „преузима улогу фокализатора и настаје прелаз у прво лице. Писац оваквим аутопоетичким поступком подиже приповедача на виши ниво и даје му ауторитет и 'власт' над наративом чији је и сам део” (Канић 2013: 141).

Синтаксичка структура поднаслова одељака показује велику разноврсност. Иако се не могу потпуно свести на моделе, кренућемо од синтаксички најједноставнијих и, поред њихове синтаксичке устројености, анализирати и њихову функцију у надређеним синтаксичким јединицама које често постоје у тексту.

Наслови који се састоје од једне лексеме, као у следећим примерима, нису фреквентни:

Механик (130); Стог (138); Зазидар (176); Повеља (185); Бекство (215); Раст (257); Пера (322).

Један од специфичних наслова овога типа састоји се од по једне непунозначне лексеме. Такав је случај са насловом „И” (Дваgесей осми gан), са текстом који се састоји од једне једине реченице: „И одмах затим, пошто су скривнице са виделима затворене, ништа се више није дало приметити" (316). Један наслов састоји се само од узвика „Ох” (172) и своју везу са текстом одељка остварује тако што сваки пасус почиње овим узвиком, чиме се анафорички наглашава поновљени елемент. Лингвистика текста овај елемент сагледава као тему исказа: „реченице у тексту обједињене су истом темом, све су оне варијанте на исту тему" (Ковачевић 2000: 294). Наслов - односно лексема у 
наслову - додатно појачава функционалну, семантичку и симболичку позицију теме.

$\mathrm{Ox}$

Ох, камо лепе срећице да се нису сви простодушни искупили, колико је могло да стане у Савину келију са радошћу да чекају од Јужних страна избављење.

Ox, тужице, како је било преподобном игуману Григорију [...]

$\mathrm{Ox}$, како је било монасима, када је гомила камена, јаука и земље затамнила једино уздање.

Ox, како је било мирјанима када су од целе Милутинове војске препознали несретног Гојка, жалосно палог на друм [...]

Ox, како је било свима док су слушали веселе усклике Бугара и Кумана. [...]

Ox, како је све то, уистину, било тужно за гледање. (172)

Чешћи су вишелексемски наслови, који имају форму од најједноставније синтагме (конгруентни атрибут + именица), преко разгранатих синтагми и конструкција, па до сложене реченице.

Најједноставнији тип синтагме, онај са конгруентним атрибутом, није посебно фреквентан, а остварује се са немаркираним редом речи. Петровић, дакле, не искоришћава ред речи као потенцијално средство архаизације, али саме лексеме у наслову преузимају ову функцију: „Летећа устава” (44), „Ревносни келијот” (45).

У синтагмама са неконгруентним атрибутом незнатно предњачи модел са атрибутом у генитиву (најчешће са посесивним значењем):

Искушење монаха Саве (91); Прашчаници св. Петра (160); Мехури Симеона Студита (242); Највештији проводаџија Републике св. Марка (84); Ударац руком о јантарну јабуку седла (40)

Међутим, свакако се издвајају паралелизми у грађењу 
наслова - двочлане, трочлане и четворочлане напоредне структуре различитог степена синтаксичке разгранатости. У оваквим насловима чланови су најчешће у саставном односу који је назначен везником $u$ :

(а) двочлане синтагме

Сребрно зрневље и тканица звукова (15); Четири стране света и четири главна смера времена (29); Мешине искри и врећица кима (62); Дуговрате цркве и ширококриле палате окружене мноштвом несносних жаба (81); Бугарски цар Калојан и његових седам дувала (261); Напуштено рухо и неми говор (286); Балиста или прашта (134); Конац или почело (370)

(б) трочлане синтагме

Хлебови, стихови и боје (62); Цвето, Тихосава, Милена! (61); Реликвије, биље и друге припреме (63); Увређене усне, овенула брада и друге невоље (143); Три обична ока, две маслине ољуштених кожица и један заветован поглед (88); Нечисто словије, разне ине злости и гмизаво љубије (273); Шест крсташа, шест Млечана и трупкање шест штапова (307); Кеса са пет сребрњака, трећа трећина лучаница и црква Св. Теодора (329)

(в) четворочлане синтагме

Утрунак, прстохват, удланица и сушена тиква (147); Бденије, несретни пад, пребијена шака и узнемирено шуштање крила (77); Танке, папирнате сличице, ретуширане илустрације, блештаве украсне фолије и обичне новине (280); Игуман Григорије, три мајстора, кефалија Величко и велика прашина (32)

По својој учесталости могу се издвојити и наслови у форми адвербатива (за место, време, друге адвербијалне категорије или њихове комбинације), често организовани као напоредне структуре:

Сред чела колоне (37); Около ове тројице (38); Негде 
између Будимље и Дабра (51); Одасвуд, ка вртложном јазу (99); Једне такве ноћи (14); Једне априлске зоре, пред одсудни бој (208); У освит, испред отворених капака (104); Испред отворених капака, нешто ближе, само дан хода од манастирске капије (110)

У складу са пажњом коју Петровић посвећује броју у структури дела, па и у структурисању наслова трећег нивоа када их одликује паралелизам, низ наслова садржи бројевне лексеме или именице од њих деривиране:

Четири стране света и четири главна смера времена (28); Кеса са тачно пет сребрњака (мада их је било равно тридесет), разговор о томе (64); Број седам стотина педесет осам (154); Осамнаест бачви сурутке (157); Стотине испружених дланова (251); Бугарски цар Калојан и његових седам дувала (261); Шест крсташа, шест Млечана и трупкање шест штапова (307).

Тридесети дан (Шеста књига) организован је у три

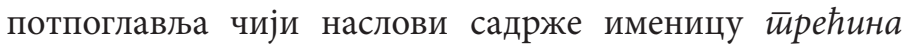
(свеће прве, друге и треће трећине које су изгореле). Тако се тридесети дан организује у три трећине сагоревања лучаница, формирајући целину која води ка невиделу: „Против воље Вишњег, гоњен грешном људском жељом, храм Св. Теодора се одмакну од Жиче, заплови вероломним путем" (331).

Неки од наслова имају форму поредбених конструкција или их укључују, на пример:

Као после какве бродоломне буре (95); Благо је њихао прозор, као да је сито за испирање злата (238).

Наслови који свакако привлаче пажњу својом комплексном синтаксичком организацијом укључују барем једну јединицу реченичног нивоа (прва група примера). 
Релативно су једноставне оне које се састоје од једне клаузе, а присутне су и независносложене и зависносложене реченице, синтаксички комплетне и са не посебно разгранатом структуром (друга група примера):

(1)

Беше подне, час тужног растанка (24); Густи драч изниче подно манастира (127); Творац је бацио прву шаку звезда (135); И настаде надвлачење између неба и земље (196); Задихано је лупао неко, из пола ноћи, по вратима млина, усамљеног у високој гори (98); Галије пристадоше у луку, а дромони на дно (155); Уз укривљена видела и сами постајемо криви (319)

(2)

Крај прозора су летеле птице и пчелиње кошање, прхтали су шестокрили серафими (70); Могло се спавати у ланеној кошуљи, а да се не добије кијавица (264).

Овде нам је да разаберемо како пошаст да дочекамо (67); Наднесеш ли се искрено, можеш да се рукујеш са звездама, сунцем или кишом (180); Трошак није ништа већи од онога колико тачно и имате (342); На вама је суште речи да спасете (335); Није него, сад ћеш нам рећи да си и рајско дрвеће упознао (193); Наднесеш ли се искрено, можеш да се рукујеш са звездама, сунцем или кишом (180).

Неки од наслова имају форму заповедне реченице, на пример:

За пример другима, добро их уваљајте у ништа (42); Чувај ce! (56); У име Отца и Сина и Светаго Духа, зде похитај ручице, тескоти забран утврди (301).

У упитној форми су наслови који имају упитну комуникативну вредност (сигнализирану упитником), али у знатно већој мери упитна реченична форма има функцију неке врсте експланативне најаве. У овом типу реги- 


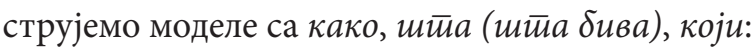

Како замишљени канали добијају обале од стварности (148); И како каналима не мора да тече само вода (151); Како је мртви Алеман стао на памет осионог властелина Прибила и од чега је великоименити краљ био непрестано жудан и у позним годинама живота (49); Као да камен са свих страна буде окренут спрам Господа (222); Свевидећи Боже, шта се то збива са оне стране? (347); Мора ли све што дува кроз Жичу да се протне? (311)

Шта бива када приче и стигови потону у хладну воду (46); И шта бива када се претерано наднесеш над судбином (189); Од чега се све састоји сто хвати у Србаља (133)

Које се речи пишу којим перима (57); Којом се птицом лови облак над степом и где се, после свега, нашла Жича (192);

Може ли перо да држи куполу (357); Умножава ли више телевизор или препукло огледало, сада без старовремских одлика (317).

Посебу пажњу, међутим, привлаче наслови у чији склоп улазе најмање две засебне информације о тексту који предстоји, те се структура оваквих наслова остварује као спој двеју синтагми, реченичног и нереченичног елемента или као спој клауза које најављују оделите сегменте даљег текста:

Висак, мајстор је затварао прозоре (182); Одметнути приповедачи, тиранија властелина историје (220); Менестрел Жофре, свако се перо гнезди у себи одговарајућим недрима (266); Архиепископ Јевстатије Други, недирнути пламсаји испод часне трпезе (314); Савина се катихуменија наврши лошим вестима, до малог ручка погоре трећина преосталих лучаница (325).

Чешће су, међутим, ови елементи - информационо 
истосмерни - само уклопљени у исту целину иако би, синтаксички, комуникативне реченице, конструкције и синтагме морале имати засебан статус:

Мимо пута спалише повесма метежа, је ли то дошло доба жетве, је ли то дошао крај века (60); Чудо св. Цара Константина и св. Царице Јелене, звоне звона (41); Шта се нашло у мрежама на јужној граници, распустите вртне чворке, зовите ми птицоносце (106); Погоре и друга трећина лучаница, има ли душу онај који прти туђе животе (327); Рекосмо ли нешто што боли, крагуј утече, тело паде у нестајање (124).

\section{4. КОРЕСПОНДЕНЦИЈА НАСЛОВА МЕБУ СОБОМ ИЛИ НАСЛОВА И ТЕКСТА}

У роману су остварени различити модели узајамне кореспонденције наслова и кореспонденције наслова и текста.

У потпоглављу Деветии gан у Кюизи gруіоо (Херувими) наслови међусобно кореспондирају: прва четири идентичним првим елементом (Призори из млаgостии), а свих седам садрже лексеме које су називи врста птица или (један) лексему од таквог назива изведену (соколар):

Призори из младости, сово покажи се (112); Призори из младости, ластавице (113); Призори из младости, штиглиц, канаринац или папагај, свеједно (114); Призори из младости, додир крила зебе (115); Соколар деспота Стефана Лазаревића (117); Пријемни испит, коме је ова ушара мршавица, а коме је краткокљуна гуска прекомерно туста (120); Рекосмо ли нешто што боли, крагуј утече, тело паде у нестајање (124).

Сви текстови на које се ови наслови односе 
„посвећени су Богдану и његовој великој љубави - птицама” (Турањанин 2014: 109), које „симболизују анђеле и виша стања бића што [...] Богданов лик подводи чвршћој концепцији романа. Такође, птица као симбол душе има улогу посредника између земље и неба" (Исто: 105).

Сличан паралелизам остварен је у сукцесивним насловима у оквиру Тринаестог дана: „Великомученити краљ Стефан Урош II Милутин, надомак Ждрела” (164) и „Богољубиви краљ Стефан Драгутин, недалеко од Ждрела” (167), као и у четвртом и петом поднаслову Осмог дана: „Иза затворених капака, олуја, мада није било ни капи кише” (101) и „У освит, иза отворених капака” (104), те у седмом: „Испред отворених капака, нешто ближе, само дан хода од манастирске капије” (110).

Сва три наслова у оквиру Триgесей сеgмог, Tрuge-

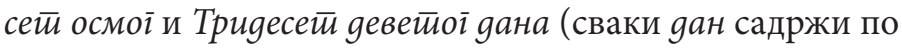
једно потпоглавље) имају исту форму (из+генитив), која прати идеју преузетог документа (текста): „Из историје” (360), „Из житија и дела благочастивога и христољубивога и светороднога, моћнога и самодржавнога са Богом господина краља Стефана Уроша Милутина, списаним од грешнога Данила” (361), „Из Политичке” (364).

Наслов или његов део најчешће кореспондира са делом текста у потпоглављу, често са почетком:

\section{Сред чела колоне}

Сред чела колоне, што се видела кроз окно садашњег на даљину, јахао је многострашни кнез видински Шишман. (37)

Около ове тројице

Около ове тројице јездила је или трчала тушта стрелаца, оклопника, лаких коњаника, стегоноша, оружара и пешака. (38)

Подједнако су стилски и функционално маркирана 
преклапања наслова и завршетака одељака, као у примеру:

Плавушно тињање лањског лишћа...

[...] Измешала се шкрипа преломљених стабала, кликтање крагуја, удар, мирис прероване земље, нешто налик смраду барута, заслепљујући пламен, бол, плавушно тињање златног лишћа...

Потом је пала потпуна тишина” (350)

Кореспонденција наслова и текста, ипак, не може се свести на типове у овом смислу. Наслови могу понављати секвенце из било којег дела текста - елементе почетка и краја, неколико елемената из различитих делова, или упућивати на лексички и(ли) синтаксички модификован текст:

Ударац руком о јантарну јабуку седла

[...] расрди се многострашни Шишман, пљесну руком о јантарну јабуку седла и пегава капа од живог риса спремно скочи са његове главе, канџи наперених у очи несретника. $(40-41)$

Две водене але, звоните звона

Није се игуман Григорије тако препао од прошле јесени, када су монаси у рибњаку мрежама уловили пар водених ала. [почетак] [...] Ударите у звона. Боже спаси, помози. Звоните звона! [крај] (39-40).

„Летећа устава” (слично као наслов „Које се речи пишу којим перима”), представља пример поднаслова који не одговара директно било којој синтагми, конструкцији или клаузи у тексту. Овај наслов обухвата веома кратак текст у којем се показује да је успостављена само посредна веза између синтагме летиећа устиава и синтагме лейећи сйвор:

Летећа устава 
Ваљда се дан у сумрак омакао, па жички монаси у насталом метежу не опазише птицу сабласног изгледа. Високо изнад манастирског дворишта, летећи створ је тромо кљувао целовит звон великог звона, бранећи да позив на помоћ одмакне, допуштајући да до Господове баште допре само ситна звека обичног земаљског дана. (44)

Посебна веза са текстом је у форми најаве и контранајаве, као у примеру (наслов у функцији најаве):

Бугари и Кумани су радили свашта, а тројица виђенијих опсадника ово: (293)

Овај поступак примењен је два пута у вези са „Крсташком песмом” и њеним аутором:

I

Крајем месеца септембра,

непосредно пре веома срамотног догађаја,

певао је артешки трувер

Конон де Бетин

прве октаве

своје чувене „Крсташке песме”:

O Аморе, тежак је растанак

Од ње која пуна је драгости,

Којој служих, о којој сних санак!

$(80-81)$

V

- Вај! Ја идем, а море ме сета, Да Бог душу прочисти ми пусту, А тек на њу што је бисер света Знајте ја ћу мислити на том путу!

- напокон је трувер Конон де Бетин, пошто се мало 
изветрио од стида, смогао снаге да катреном доврши своју „Крсташку песму”. (90)

\section{5. ЗАКЉУЧАК}

У анализираном роману наслови већих јединица (књиіа и gана) су униформни по лексичкој и синтаксичкој организацији, али су носиоци идејног и симболичког плана романа. Међутим, наслови најмањих целина на које се текст рашчлањује показују изразиту разноврсност, пре свега у синтаксичкој организацији и разуђености.

Са стилског аспекта, одликују се свакако лексичким саставом, али и паралелизмима, како у оквиру самих наслова, тако и у вези са другим (по распореду у роману блиским) насловима.

Посебан аспект њихове стилематичности остварује се у типовима њиховог кореспондирања са текстом који најављују.

\section{ИЗВОРИ И ЛИТЕРАТУРА}

Алексић 2013: Ј. Алексић, Ойсеgнуйа ӥрича. Поейика романа Горана Пеитровића, Београд: Службени гласник.

Интервју, Горан Петровић: На кафи са ауйором од 29. 6. 2018, https://www.youtube.com/watch?v=W_RjPByWSHs

Канић 2013: М. Канић, Византиија у срйској йостимовернистиччкој йрози (Борислав Пекић, Милораg Павић, Горан Пейровић и Раgостав Петиковић), докторска дисертација, Универзитет у Београду, Филолошки факултет.

Ковачевић 2000: М. Ковачевић, Сииилистика и ірамайика сииллских фиіура, Крагујевац: Кантакузин.

Ле Гоф 2007: Ж. ле Гоф, Човек среgюеї века, Београд: Клио. Микић 2005: Р. Микић, Прича и значењее. Оіллеgи о умейносиии 
йриӣовеgаюа. Београд: Филип Вишњић.

Перишић 2006: И. Перишић, „Од постмодернизма ка новој утопији", Кюижевна истиорија XXXVIII, св. 128-129, 403-425.

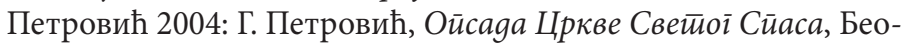
град: народна књига - Алфа, 8. издање.

Ристић Горгиев 2003: С. Ристић Горгиев, „Појам лепог у Византији”, у: М. Ракоција (ур.), Ниш и Визанӣија, књ. 1. Ниш: Град Ниш - Просвета, 190-198.

Трифуновић 1990: Ђ. Трифуновић, Азбучник срӣских среgюовековних кюижевних йојмова, Београд: Нолит.

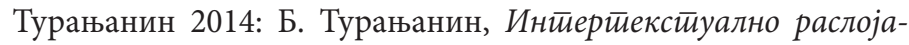
ване романа „Ойсаgа иркве Свет̄оі Сйаса” Горана Пеитро-

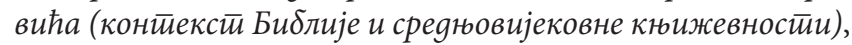
докторска дисертација, Универзитет у Новом Саду, Филозофски факултет.

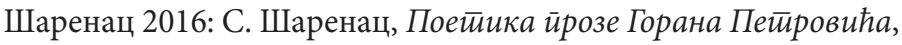
докторска дисертација, Универзитет у Београду, Филолошки факултет. 
Ilijana R. Čutura

\section{SYNTAX AND STYLISTICS OF HEADINGS IN THE NOVEL OPSADA CRKVE SVETOG SPASA}

\section{Summary}

The paper analyses syntactic and stislistic features of headings in the novel Opsada Crkeve Svetog Spasa (The Blocade of the Curch of Holy Salvation) by Goran Petrović. Numerous headings, which are organized in three levels, correspond to fragmentarity of the text (as a sign of postmodern deconstruction).

Headings which belong to the first and the second level are unified in the sense of lexis and syntax, but they represent symbolic plan of the novel. Headings of the third level show a great variety in syntax and lexic. They have forms of words, constructions, clauses or sentences, and always correspond with the following text and with the philosophy behind the entire text.

Key words: titles, Goran Petrovic, novel Opsada Crkve Svetog Spasa (Siege of the Church of the Holy Savior), syntactic organization of titles, stylistics of titles. 